Przegląd Prawa Konstytucyjnego

-----ISSN 2082-1212-----

DOI 10.15804/ppk.2018.03.06

-----Nr $3(43) / 2018-----$

\title{
Recenzja
}

\section{Jerzy Kuciński, Sejmowa kontrola dziatalności rządu z perspektywy prawnoustrojowej i praktyki politycznej, ISBN 978-83-8017-146-6, Wydawnictwo Elipsa, Warszawa 2017, ss. 472}

Problematyka realizacji przez Sejm kontroli nad działalnością Rady Ministrów należy do szczególnie interesujących, nie tylko ze względu na wielość i różnorodność mechanizmów pozwalających organowi przedstawicielskiemu na dokonywanie oceny sposobu wykonywania konstytucyjnych zadań przez poszczególnych członków rządu, jak i cały gabinet. Kontrola jest poza tym zjawiskiem żywym, budzącym nierzadko sporo emocji, pokazującym niuanse funkcjonowania Sejmu. Stąd z dużym zainteresowaniem należy przyjąć publikację autorstwa Jerzego Kucińskiego, zatytułowaną Sejmowa kontrola działalności rządu z perspektywy prawnoustrojowej i praktyki politycznej, która ukazała się nakładem wydawnictwa Elipsa.

Publikacja składa się z siedmiu rozdziałów, zakończonych konkluzjami. We wstępie autor podkreśla, że rozważania na temat „sejmowej kontroli działalności rządu” prowadzone są na czterech „wyodrębnionych umownie płaszczyznach”. Pierwsza odnosi się do naczelnych zasad ustroju, będących podstawą unormowań prawnych problemów sejmowej kontroli działalności rządu, kolejna ukazuje sejmową kontrolę w kontekście „nieodzownego składnika konstytucyjnego systemu rządów”. Trzecia płaszczyzna obejmuje konkretne instytucje pozwalające Sejmowi kontrolować rząd, czwarta zaś odpowiedzial- 
ność parlamentarną Rady Ministrów i jej członków przed Sejmem (s. 14-15). Mając świadomość, że ujęcie sejmowej kontroli nad rządem tylko przez pryzmat oceny przyjętych rozwiązań prawnych nie jest wystarczające, J. Kuciński uwzględnił w pracy „w jak najszerszym możliwym zakresie” praktykę polityczna i parlamentarną. I niewątpliwie szerokie podejście do kontroli sejmowej, uwzględniające rozwiązania normatywne i odwołujące się do praktyki parlamentarnej stanowi ogromną zaletę recenzowanej publikacji.

Pierwszy rozdział książki poświęcony jest pojęciu sejmowej kontroli działalności rządu. Po dosyć syntetycznym przedstawieniu poglądów Trybunału Konstytucyjnego na temat kontroli sejmowej, autor podjął się trudnego zadania przeanalizowania i przedstawienia poglądów przedstawicieli nauki prawa konstytucyjnego i politologii na temat pojęcia kontroli sejmowej. Uczynił to w trzech grupach: 1) zastosowanej terminologii, 2) proponowanych klasyfikacji sejmowej kontroli, 3) zanalizowania stanowisk w kwestii określenia treści pojęcia „kontrola sejmowa (parlamentarna)”. Przyjęta przez J. Kucińskiego metodologia sprawia, że zapoznanie się z poglądami przedstawicieli nauki na problematykę kontroli może nie należy do najłatwiejszych, ale niesie ze sobą wiele walorów poznawczych. Autor niemal z detaliczną precyzją „rozbiera” kontrolę sejmową na czynniki pierwsze, wskazując na pojawiające się $\mathrm{w}$ definicjach formułowanych przez przedstawicieli nauki elementy takie jak: podmioty sprawujące kontrolę, zakres kontroli, instrumentarium kontroli, instrumenty kontroli, formy kontroli sejmowej, by następnie skupić się na wyróżnieniu rodzajów kontroli i dokonać klasyfikacji kontroli sejmowej. Ten zabieg nie wydaje się w pełni zrozumiały, bowiem próby osadzenia kontroli sejmowej w ramach teoretycznie wyróżnionych rodzajów kontroli prowadzić mogą jedynie do wniosku, że kontrola sejmowa może być zarówno kontrolą prewencyjną, jak i represyjną, kontrolą całościową i kontrolą częściową. Wydaje się, że bardziej uzasadnione byłoby ujęcie w tych klasyfikacjach konkretnych instrumentów kontroli.

W rozdziale drugim J. Kuciński omawia sejmową kontrolę działalności rządu w kontekście wybranych, naczelnych zasad Konstytucji z 2 kwietnia 1997 r. - zasady demokratycznego państwa prawnego, zasady podziału władzy i równoważenia władz, zasady zwierzchnictwa narody, oraz zasady określającej podstawowe postacie sprawowania władzy przez naród. Pozwala to czytelnikowi spojrzeć na konstytucyjną funkcję kontrolną Sejmu głębiej i oprzeć 
ją na przyjętym i wyrażonym w konstytucyjnych zasadach systemie wartości, na których opiera się funkcjonowanie państwa polskiego.

Problematyka zakresu podmiotowego i przedmiotowego kontroli prowadzonej przez Sejm stała się przedmiotem rozważań ujętych w kolejnym rozdziale publikacji. W pełni należy zaakceptować stanowisko zaprezentowane przez J. Kucińskiego, że użyte przez ustawodawcę konstytucyjnego określenie, że Sejm sprawuje kontrolę nad działalnością Rady Ministrów należy odczytywać szeroko. Kontrolą ze strony organu przedstawicielskiego objęty jest kolegialny organ władzy wykonawczej, jakim jest Rada Ministrów, ale kontrolna aktywność Sejmu obejmuje również członków Rady Ministrów - Prezesa Rady Ministrów, ministrów resortowych, ministrów wykonujących zadania zlecone przez prezesa Rady Ministrów, wiceprezesów Rady Ministrów, przewodniczących określonych w ustawie komitetów wchodzących w skład Rady Ministrów, a także całą administrację rządową. Jak słusznie wskazuje autor „nie sposób precyzyjnie oddzielić Rady Ministrów od całej administracji rządowej, która jest Radzie Ministrów podporządkowana i realizuje wytyczoną przez nią politykę...” (s. 113). Przyjmując założenie o konieczności szerokiego traktowania Rady Ministrów w kontekście sejmowej kontroli, w kolejnych częściach rozdziału III autor dokonał szczegółowej analizy podmiotów poddanych kontroli (Rady Ministrów, Prezesa Rady Ministrów, ministrów) omawiając ich miejsce w systemie organów państwowych, powoływanie, zasady funkcjonowania. Wiele uwagi zostało poświęconej zagadnieniu „działalności Rady Ministrów” będącej przedmiotem kontroli sejmowej. Kluczowy w tej materii art. 146 ustawy zasadniczej oprócz wskazania, że Rada Ministrów prowadzi politykę zagraniczną i wewnętrzną państwa i powiązania z działalności rządu zasady domniemania kompetencji, w ustępie 4 wskazuje zadania i kompetencje Rady Ministrów. Autor wskazując na różnice w pojęciach funkcje (określone konstytucyjnie podstawowe kierunki działalności Rady Ministrów) i kompetencje (zespół uprawnień przyznanych przez prawo danemu organowi oraz prawnie określonych jego obowiązków) (s. 127), na kolejnych kartach publikacji wyróżnia pięć grup kompetencji mogących być przedmiotem kontroli ze strony Sejmu: kompetencje ze sfery rządzenia państwem, kompetencje wykonawcze, kompetencje w sprawach związanych z członkostwem RP w Unii Europejskiej, kompetencje kierowniczo-koordynacyjne oraz inne kompetencje. Przyjęcie takiego rozróżnienia pozwala w sze- 
rokim świetle spojrzeć za obszar właściwości Rady Ministrów, a także uzmysłowić sobie zakres działań kontrolnych.

Kolejne rozdziały publikacji wpisują się w powszechnie przyjętą koncepcję analizy instrumentów kontroli sejmowej służących Sejmowi działającemu in pleno (rozdział IV), kontroli sprawowanej przez komisje sejmowe (rozdział V) oraz kontroli sprawowanie przez posłów (rozdział VI). W każdym z tych rozdziałów autor rozważania rozpoczyna od przedstawienia pozycji ustrojowej kontrolującego podmiotu, by następnie dokonać szczegółowego omówienia mechanizmów służących prowadzeniu kontroli, poprzez przedstawienie elementów procedury i praktyki parlamentarnej.

Kontrola sprawowana przez Sejm działający jako cała izba prowadzona na posiedzeniach plenarnych. Przedstawiając posiedzenia plenarne jako forum kontroli działalności Sejmu, autor odniósł się do trybu pracy Sejmu, zasady jawności posiedzeń Sejmu (z punktu widzenia nauki prawa konstytucyjnego właściwszym wydaje się używanie określenia zasada, a nie, jak czyni to to Autor - reguła), a także, nabierającej szczególnego znaczenia dla prowadzonych działań kontrolnych, zwłaszcza w kontekście działalności sejmowych komisji śledczych i działalności Komisji Odpowiedzialności Konstytucyjnej, zasady dyskontynuacji prac Sejmu. Można w tym miejscu postawić pytanie o cel wyróżnienia „posiedzeń kontrolnych”, skoro sam autor wskazuje na stronie 171, że „zazwyczaj porządek dzienny posiedzenia nazwanego w pracy posiedzeniem kontrolnym obejmował także inne sprawy, przy czym najczęściej zagadnienia kontroli nie zajmowały pierwszoplanowego miejsca w porządku dziennym posiedzenia izby".

Do instrumentów kontroli wykorzystywanych przez Sejm działający in pleno J. Kuciński zaliczył: prawo do uzyskiwania przez Izbę informacji o działalności kontrolowanych organów rządowych, prawo Sejmu do zapewnienia obecności przedstawicieli kontrolowanych organów rządowych na posiedzeniach izby. Natomiast do form kontroli: rozpatrywanie przez Sejm sprawozdań Rady Ministrów z wykonywania ustawy budżetowej i podejmowanie uchwał w przedmiocie absolutorium dla rządu, kontrole problemowe poszczególnych dziedzin działalności rządu prowadzone przez Sejm in pleno oraz pozostające z nimi w związku uchwały i rezolucje izby. W szczególny sposób należy podkreślić, że rozważania autora oparte są na analizie obowiązujących przepisów, jak również w szeroki sposób odwołują się do praktyki parlamentar- 
nej. Przedstawione przez autora dane statystyczne, nie tylko wprost odnoszą się do realizacji funkcji kontrolnej przez Sejm, ale również obrazują działania kontrolne prowadzone przez Najwyższą Izbę Kontroli, a których efekty mogą być wykorzystane przez Sejm (np. tabela nr 3 Aktywność kontrolna NIK w odniesieniu dla organów rządowych, s. 177-178). Warto zwrócić również uwagę na rzadko poruszany w nauce prawa konstytucyjnego element działalności Sejmu, wpisujący się w realizację funkcji kontrolnej, jakim jest rozpatrywanie przez Sejm informacji i sprawozdań rządowych. Omawiając działania kontrolne podejmowane przez całą izbę, autor posłużył się pojęciem „kontrole problemowe” i pomimo tego, co sam J. Kuciński podkreśla, że ani Konstytucja ani regulamin Sejmu nie posługują się tym pojęciem, to art. 95 ust. 2 Konstytucji „stwarza Sejmowi in pleno wystarczająco silną legitymację dla prowadzenia kontroli problemowych poszczególnych dziedzin działalności rządu" (s. 208). Tu autor wskazuje przede wszystkim na kontrolę działalności Rady Ministrów w Unii Europejskiej, ale także podaje dane na temat ilości i treści informacji przedstawionych Sejmowi w kadencjach III - VII.

Kontrolnej działalności komisji sejmowych poświęcony został rozdział V publikacji. W powszechnym odbiorze najczęstsze skojarzenia działalności kontrolnej komisji wiążą się z powoływanymi na podstawie art. 111 Konstytucji komisjami śledczymi. Problematyka to stała się przedmiotem wielu publikacji, na które także wskazuje autor (przypis 2, s. 233) i została dosyć wszechstronnie przedstawiona, także w recenzowanej publikacji. Natomiast w odniesieniu do działań o charakterze kontrolnym podejmowanych głownie przez komisje stałe Sejmu można mówić o istnieniu pewnej luki w literaturze, którą z powodzeniem wypełnia publikacja J. Kucińskiego. Autor nie tylko przedstawił dane dotyczące posiedzeń komisji, ale podjął się również żmudnego zadania przeanalizowania przedmiotu posiedzeń komisji pod kątem realizowania przez nie działań kontrolnych. Niezwykle ciekawym na tym tle jest także przedstawienie zakresu przedmiotowego i adresatów dezyderatów kierowanych w poszczególnych kadencjach Sejmu (III-VII).

Bez wątpienia w ramach kontroli sejmowej nad działalnością Rady Ministrów ważne miejsce zajmują instrumenty kontroli, z których korzystać mogą indywidualnie posłowie. Mowa tu o interpelacjach poselskich, zapytaniach, pytaniach w sprawach bieżących oraz informacji bieżącej. Wskazane instrumenty kontroli są nader często wykorzystywane przez posłów, niemniej 
na podstawie informacji o działalności Sejmu nasuwa się wniosek, że posłowie najczęściej wykorzystują interpelacje poselskie do uzyskania informacji o działaniach rządu czy poszczególnych jego członków. Trzeba podkreślić, że J. Kuciński nie poprzestał jedynie na przeanalizowaniu procedury określającej występowanie przez posłów z interpelacjami, ale odniósł się także do drugiej strony interpelacji - odpowiedzi interpelantów na zawarte w nich pytania (s. 371-373). To bowiem pozwala ocenić w jakim stopniu członkowie Rady Ministrów wywiązują się z konstytucyjnego obowiązku udzielania odpowiedzi na interpelacje.

Stosunkowo nowym instrumentem kontroli jest informacja bieżąca, wprowadzona do regulaminu Sejmu w 2003 r. Analizując podstawy normatywne informacji bieżącej, autor stwierdził, że wprowadzenie tej instytucji nastąpiło „bez podstawy konstytucyjnej i ustawowej” a to „rodzi poważne wątpliwości co do zgodności takiego stanu prawnego zarówno z przepisem art. 95 ust. 2 Konstytucji, jak i z przepisem art. 112 oraz art. 7.” Trudno się z tym twierdzeniem zgodzić, bowiem art. 115 ust. 2 (który zdaniem J. Kucińskiego, nie pozwala na wprowadzenie tej instytucji) nakłada na Radę Ministrów obowiązek udzielania odpowiedzi w sprawach bieżących, nie zawężając tego obowiązku jedynie do odpowiedzi na pytanie skierowane przez posła. Wydaje się, że w art. 115 ust. 2 Konstytucji ciężar został położony na kwestiach uzyskiwania od rządu i jego członków informacji o sprawach, którymi aktualnie zajmuje się i w tym kontekście należy uznać, że informacja bieżąca znajduje konstytucyjne umocowanie.

W ostatnim rozdziale książki autor przedstawił mechanizmy odpowiedzialności parlamentarnej Rady Ministrów i jej członków - konstruktywne $\mathrm{i}$ indywidualne wotum nieufności oraz wotum zaufania $\mathrm{z}$ art. 160 Konstytucji. Ich analiza, oparta także na praktyce parlamentarnej pozwoliła autorowi sformułować dwie konkluzje, z którymi należy w pełni się zgodzić. W pierwszej J. Kuciński podkreśla, że istnienie partii politycznych, jednorodność polityczna większości parlamentarnej i rządu doprowadziły do zmiany reguł odpowiedzialności parlamentarnej i zmniejszenia roli opozycji politycznej. W drugiej podnosi, że „Zwartość większości parlamentarnej” skutkuje skłonnością tej większości parlamentarnej do niewykorzystywania instytucji odpowiedzialności parlamentarnej. 
Całość pracy kończą konkluzje autora wnioski de lege ferenda. Wśród nich można wskazać w szczególności na postulat zlikwidowania indywidualnego wotum nieufności lub dokonanie zmian w jego procedurze, rozważanie celowości utrzymywania wotum zaufania udzielanego Radzie Ministrów w czasie jej funkcjonowania czy podwyższenie wymogów formalnoprawnych przy podejmowaniu przez Sejm uchwały w przedmiocie absolutorium dla rządu oraz sprecyzowanie skutków prawnych nieudzielenia przez Sejm absolutorium Radzie Ministrów.

Recenzowana publikacja stanowi niewątpliwie ważny wkład w rozwój nauki prawa konstytucyjnego oraz politologii. Pozwala czytelnikowi skoncentrować się na dwóch pozostających ze sobą w ścisłej korelacji zagadnieniach sejmowej kontroli - podstawach normatywnych mechanizmów kontroli i elementów proceduralnych oraz praktyki parlamentarnej. Tylko bowiem spojrzenie przez oba pryzmaty umożliwia dostrzeżenie wszelkich aspektów realizacji funkcji kontrolnej. Raz jeszcze wypada także podkreślić, że autor rozważania teoretyczne uzupełnił elementami praktyki, co wymagało wielkiego wysiłku, ale bez wątpienia stanowi o wartości publikacji. Rzetelność naukowa z jaką J. Kuciński podszedł do problematyki sejmowej kontroli nad działalnością Rady Ministrów i precyzja wywodu sprawiają, że do rąk czytelników trafia publikacja, którą z pełną odpowiedzialnością można polecić.

Joanna Juchniewicz Uniwersytet Warmińsko-Mazurski w Olsztynie 